\title{
Effect of Media Types and Carbon Sources on In vitro Shoot Proliferation of Spilanthes acmella (L.) Murray
}

\author{
Veenu Joshi and S.K. Jadhav* \\ School of Studies in Biotechnology, Pt. Ravishankar Shukla University, Raipur-492010, \\ Chhattisgarh, India
}

Key words: Spilanthes acmella, Effect of media, Carbon sources, Shoot proliferation

The present study reports the evaluation of the effects of different media and carbon sources on in vitro shoot proliferation of Spilanthes acmella by culturing nodal segments on different basal media (MS, B5, N \& N, WM and LS) and MS supplemented with different carbon sources (Sucrose, glucose, maltose and lactose). Maximum shoot length and leaf number was found with MS but there is no significant difference in shoot number obtained in different media except B5 which gave lowest number of shoot. Regarding carbon sources maximum shoot number and leaf number was found with $3 \%$ glucose and maximum shoot length was found with $3 \%$ sucrose.

Shoot proliferation using in vitro technique plays an important role in mass multiplication to ensure the easy availability of identical, disease free and good quality plant material throughout the year. Medium constitution is one of the several factors responsible for successful growth of plants in in vitro cultures. Different types of basal media used in plant tissue culture vary in the concentration of macro and microelements which greatly affects the in vitro growth and multiplication of shoots. MS is the most popular medium which has been found to be more effective than other media by many investigators. However, in several studies medium other than MS has been found to produce better growth (Tefera and Wannakrairoj 2004, Komalavalli and Rao 2000) as the optimal growth and morphogenesis of tissues vary for different plants according to their nutritional requirements.

Apart from this, type and concentration of carbon sources in the medium affects the physiology and differentiation of tissues (Lipavska and Konradova 2004) while serving as osmoticum and energy source. Generally, sucrose is the

*Author for correspondence: <shailesh_07@sify.com>. 
most popular carbon source in tissue culture media, however, it has been reported that invertases that are released by the explant into the medium split sucrose in to glucose and fructose (Goerge 1993) thus the explants are usually exposed to a mixture of sucrose, glucose and fructose. Moreover, several studies reported that different carbohydrates produce distinct effects on tissue morphogenesis in different plant species (Welander et al. 1989, Dobránszki and Silva 2010).

Spilanthes acmella (L.) Murray (Asteraceae) reported as an acutely endangered plant species is a rich source of alkamide - Spilanthol. Alkamides are known for their insecticidal and larvicidal nature. The plant has the potential to be developed into a potent antimalarial agent. Traditionally, it has been used in curing toothache, flu, cough, stammering etc. by trival people. In addition, it possesses diuretic, antioxidant, antinociception, vasorelaxant, anti-inflammatory, analgesic, antimicrobial, immunomodulatory, and aphrodisiac (Tiwari et al. 2011). Several preparations of $S$. acmella like declatone neck-antiwrinkle cream, sinus support formula "intensify" and "Spilanthes supreme" - an antiviral formula are commercially available. There are some reports available on the in vitro culture of S. acmella (Saritha et al. 2002, Pandey and Agrawal 2009) but none of the researchers have studied the effects of different types of media and carbon sources. Therefore, the present study was undertaken with a view to studying the influence of basal media types and concentration and types of carbon sources on in vitro shoot proliferation of $S$. acmella.

Healthy and young nodal segments of $S$. acmella were collected from Pt. Ravishankar Shukla University Campus, Raipur, Chhattisgarh. Nodal segments were washed under running tap water and surface sterilized by $0.1 \% \mathrm{HgCl}_{2}$ for 5 min and placed on MS supplemented by $0.5 \mathrm{mg} / \mathrm{l} \mathrm{BA}$ after several washes with sterilized distilled water. Culture initiation was followed by two subsequent subcultures to obtain in vitro nodal explants which were then cultured on five different basal media MS, B5 (Gamborg et al. 1968), NN (Nitsch and Nitsch 1969), WM (White 1963) and LS (Linsmaier and Skoog 1965) media procured from HiMedia Laboratories. All the basal media were supplemented with 3\% sucrose and gelled with $0.8 \%$ agar. For each media three treatments with $0.5 \mathrm{BA}, 1 \mathrm{mg} / 1$ $\mathrm{Kn}$ and without any growth regulator were used.

In vitro nodal explants were also cultured on MS supplemented with $1 \mathrm{mg} / 1$ $\mathrm{Kn}$ and four different carbon sources sucrose, lactose, maltose and glucose procured from HiMedia Labs in 1, 3 and $6 \%(\mathrm{w} / \mathrm{v})$ concentrations.

In all the experiments cultures were incubated at $25 \pm 2^{\circ} \mathrm{C}$ under $16 \mathrm{hrs}$ photoperiod provided by cool white fluorescent tubes (Philips, India). Each treatment had ten replicates with one explant each. Observations were recorded 
for number of shoots per explant, length of shoots and number of leaves. The treatment means were compared using DMRT at a 5\% probability level using SPSS 16 statistical package.

Effects of different media types on shoot proliferation and growth of plant in culture were examined but there were no significant differences found between the media tested on mean shoot number but maximum shoot number was found with $1 \mathrm{mg} / \mathrm{l} \mathrm{Kn}$ irrespective of the type of media and minimum with media without any plant growth regulator. Maximum mean shoot length $(6.33 \pm 0.42$ $\mathrm{cm})$ and leaf number $(8.56 \pm 0.54)$ was found with MS which is significantly higher than others. Similar results were also found in Eclipta alba (Bhaskaran and Jayabalan 2005) which may be due to relatively higher supply of nitrate-nitrogen within the MS. Since ratio of nitrate to ammonium influences the $\mathrm{pH}$ of the medium and in turn determines the absorption of other nutrients (Ramage and Williams 2002). However, minimum growth was observed in WM media (Table 1).

Table 1. Effects of different types of media on shoot proliferation.

\begin{tabular}{|c|c|c|c|c|}
\hline Media type & $\begin{array}{l}\text { PGR conc. } \\
\mathrm{mg} / \mathrm{l}\end{array}$ & $\begin{array}{l}\text { Shoot No. } \\
(\text { Mean } \pm \text { SE) }\end{array}$ & $\begin{array}{l}\text { Shoot length } \\
(\text { Mean } \pm \text { SE) } \mathrm{cm}\end{array}$ & $\begin{array}{l}\text { Leaf No. } \\
(\text { Mean } \pm S E)\end{array}$ \\
\hline \multirow[t]{3}{*}{ MS } & 0 & $1.75 \pm 0.13$ & $6.45 \pm 0.73$ & $8.86 \pm 0.91$ \\
\hline & $0.5 \mathrm{BA}$ & $2.38 \pm 0.10$ & $6.31 \pm 0.66$ & $10.6 \pm 0.52$ \\
\hline & $1 \mathrm{Kn}$ & $3.10 \pm 0.23$ & $4.60 \pm 0.32$ & $5.19 \pm 0.61$ \\
\hline Total mean & & $2.30^{b c} \pm 0.15$ & $6.33^{c} \pm 0.42$ & $8.56^{c} \pm 0.54$ \\
\hline \multirow[t]{3}{*}{ WM } & 0 & $1.90 \pm 0.10$ & $0.63 \pm 0.08$ & $2.80 \pm 0.29$ \\
\hline & $0.5 \mathrm{BA}$ & $2.00 \pm 0.00$ & $0.72 \pm 0.08$ & $3.80 \pm 0.41$ \\
\hline & $1 \mathrm{Kn}$ & $2.00 \pm 0.00$ & $0.58 \pm 0.20$ & $3.10 \pm 0.31$ \\
\hline Total mean & & $1.96^{\mathrm{ab}} \pm 0.03$ & $0.64^{a} \pm 0.07$ & $3.23^{a} \pm 0.20$ \\
\hline \multirow[t]{3}{*}{ B5 } & 0 & $1.50 \pm 0.16$ & $5.37 \pm 0.28$ & $8.30 \pm 0.88$ \\
\hline & $0.5 \mathrm{BA}$ & $1.80 \pm 0.29$ & $3.65 \pm 0.62$ & $7.65 \pm 0.33$ \\
\hline & $1 \mathrm{Kn}$ & $2.20 \pm 0.20$ & $3.25 \pm 0.20$ & $6.36 \pm 0.45$ \\
\hline Total mean & & $1.83^{a} \pm 0.13$ & $3.66^{b} \pm 0.23$ & $5.53^{b} \pm 0.25$ \\
\hline \multirow[t]{3}{*}{$N \& N$} & 0 & $2.00 \pm 0.00$ & $6.50 \pm 0.45$ & $9.20 \pm 0.38$ \\
\hline & $0.5 \mathrm{BA}$ & $2.60 \pm 0.30$ & $2.14 \pm 0.27$ & $3.89 \pm 0.28$ \\
\hline & $1 \mathrm{Kn}$ & $3.30 \pm 0.26$ & $1.19 \pm 0.16$ & $5.60 \pm 0.59$ \\
\hline Total mean & & $2.63^{c} \pm 0.16$ & $3.28^{b} \pm 0.46$ & $6.23^{b} \pm 0.47$ \\
\hline \multirow[t]{3}{*}{ LS } & 0 & $1.50 \pm 0.16$ & $7.17 \pm 0.60$ & $9.40 \pm 0.58$ \\
\hline & $0.5 \mathrm{BA}$ & $1.80 \pm 0.29$ & $1.87 \pm 0.23$ & $4.46 \pm 0.36$ \\
\hline & $1 \mathrm{Kn}$ & $2.20 \pm 0.25$ & $1.65 \pm 0.35$ & $5.36 \pm 0.43$ \\
\hline Total mean & & $2.43^{c} \pm 0.18$ & $3.56^{b} \pm 0.53$ & $6.40^{b} \pm 0.47$ \\
\hline
\end{tabular}

PGR - Plant growth regulator, WM - White's media, B5 - Gamborg's B5 media, N\&N -Nitsch \& Nitsch media, LS - Linsmeir \& Skoog's medium. All the values are mean and standard error, mean followed by different letters differ significantly at $5 \%$ level as analysed by DMRT. 
Among the four carbon sources maximum shoot $(2.80 \pm 0.22)$ and leaf number $(10.80 \pm 0.36)$ was found with $3 \%$ glucose and maximum shoot length $(6.31 \pm 0.66 \mathrm{~cm})$ was found with $3 \%$ sucrose but the difference between the results with $3 \%$ sucrose and glucose were insignificant. These are significantly different from mean results found with maltose and lactose with lactose giving minimum growth (Table 2). Similar results were reported in sour cherry (Borkowska and Szczerba 1991) where sucrose and glucose gave a similar rate of proliferation. Regarding concentration of carbon source, mean shoot number, length and leaf number first increased with the increase in concentration of carbon source up to $3 \%$ thereby decreasing at $6 \%$ irrespective of carbon source. Supplement of $6 \%$ sucrose and $6 \%$ glucose produced roots in the plantlets which may be due to the increased osmotic stress.

Table 2. Effect of different carbon sources on shoot proliferation.

\begin{tabular}{|c|c|c|c|c|c|}
\hline $\begin{array}{l}\text { Carbon } \\
\text { source }\end{array}$ & $\begin{array}{l}\text { Conc. } \\
(\%)\end{array}$ & $\begin{array}{l}\text { Shoot No. } \\
(\text { Mean } \pm \text { SE })\end{array}$ & $\begin{array}{l}\text { Shoot length } \\
(\text { Mean } \pm \text { SE })\end{array}$ & $\begin{array}{l}\text { Leaf No. } \\
(\text { Mean } \pm \text { SE) }\end{array}$ & Rooting \\
\hline Control & & $1.10^{a} \pm 0.27$ & $1.90^{\mathrm{b}} \pm 0.42$ & $2.68^{a} \pm 0.58$ & \\
\hline \multirow[t]{3}{*}{ Sucrose } & 1 & $2.10 \mathrm{~d} \pm 0.17$ & $3.88^{c} \pm 0.43$ & $7.86^{c} \pm 0.39$ & Absent \\
\hline & 3 & $2.30^{\mathrm{e}} \pm 0.10$ & $6.31^{d} \pm 0.66$ & $10.60^{d} \pm 0.52$ & $"$ \\
\hline & 6 & $2.00^{\mathrm{cd}} \pm 0.00$ & $2.51^{b} \pm 0.41$ & $5.70^{b} \pm 0.53$ & Present \\
\hline \multirow[t]{3}{*}{ Glucose } & 1 & $1.60^{\mathrm{abcd}} \pm 0.16$ & $4.80^{c} \pm 0.20$ & $8.60^{c} \pm 0.58$ & Absent \\
\hline & 3 & $2.80^{\mathrm{e}} \pm 0.22$ & $6.27^{d} \pm 0.27$ & $10.80^{d} \pm 0.36$ & $"$ \\
\hline & 6 & $2.10^{\mathrm{d}} \pm 0.15$ & $1.88^{b} \pm 0.35$ & $5.90^{\mathrm{b}} \pm 0.73$ & Present \\
\hline \multirow[t]{3}{*}{ Maltose } & 1 & $1.80^{\mathrm{bcd}} \pm 0.20$ & $2.07^{b} \pm 0.30$ & $5.30^{b} \pm 0.26$ & Absent \\
\hline & 3 & $2.20^{\mathrm{cd}} \pm 0.24$ & $1.83^{b} \pm 0.48$ & $6.10^{b} \pm 0.69$ & $"$ \\
\hline & 6 & $1.40^{\mathrm{abc}} \pm 0.00$ & $0.54^{a} \pm 0.02$ & $2.71^{a} \pm 0.25$ & $"$ \\
\hline \multirow[t]{3}{*}{ Lactose } & 1 & $1.60^{\mathrm{abcd}} \pm 0.00$ & $0.54^{a} \pm 0.15$ & $3.20^{a} \pm 0.64$ & $"$ \\
\hline & 3 & $1.20^{\mathrm{ab}} \pm 0.29$ & $0.42^{a} \pm 0.13$ & $1.80^{a} \pm 0.46$ & $"$ \\
\hline & 6 & 0 & 0 & 0 & $"$ \\
\hline
\end{tabular}

All the values are mean \pm standard error, means followed by different letters differ significantly at $5 \%$ level as analysed by DMRT.

Therefore, it can be concluded that in vitro shoot proliferation of S. acmella was best in MS and 3\% sucrose and glucose were equally beneficial for producing good shoot number and length in comparison to maltose and lactose. 


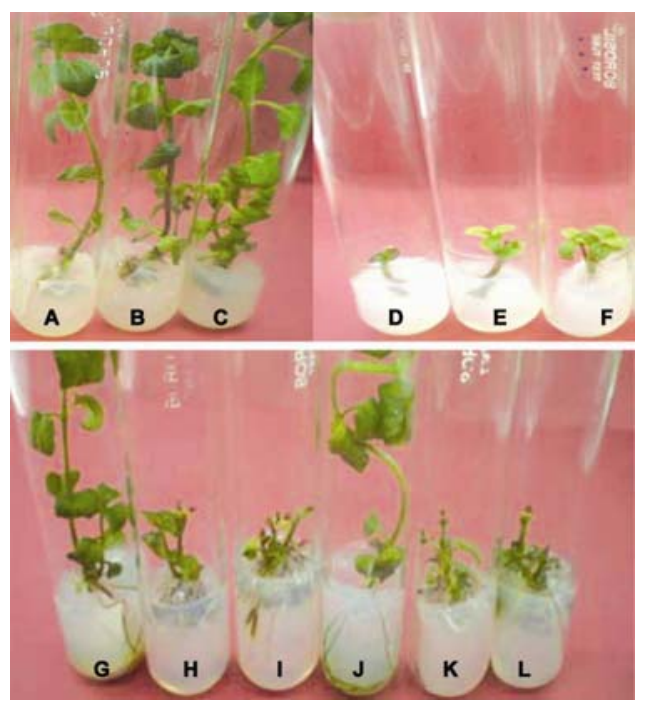

Fig. 1. Effect of different media types in vitro shoot proliferation of S. acmella. A. 0 PG. B. 0.5 BA. C. $1 \mathrm{Kn}$ (MS). D. 0 PG. E. 0.5 BA. F. 1 Kn (WM). G. 0 PG. H. 0.5 BA. I. 1 Kn (N\&N); J. 0 PG. K. 0.5 BA. L. 1 Kn (LS).

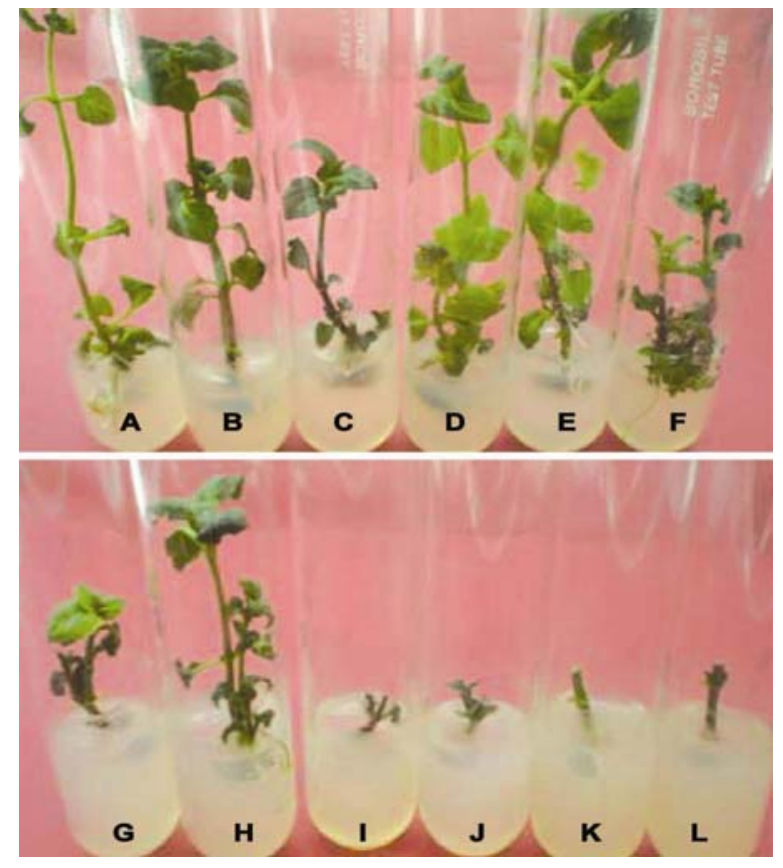

Fig. 2. Effect of different carbon sources on in vitro shoot proliferation in S. acmella. A. (MS) $+1 \%$ sucrose, B. $3 \%$ sucrose, C. $6 \%$ sucrose, D. $1 \%$ glucose, E. $3 \%$ glucose, F. $6 \%$ glucose, G. $1 \%$ maltose, H. $3 \%$ maltose, I. $6 \%$ maltose, J. $1 \%$ lactose, K. $3 \%$ lactose, L. $6 \%$ lactose. 


\section{Acknowledgement}

Authors are grateful to CSIR, New Delhi for providing financial assistance.

\section{References}

Bhaskaran M and Jayabalan N (2005) An Efficient Micropropagation System for Eclipta Alba - A Valuable Medicinal Herb. In Vitro Cell Dev. Biol. - Plant. 41: 532-539.

Borkowska B and Szczerba J (1991) Influence of different carbon sources on invertase activity and growth of sour cherry (Prunus cerasus L.) shoot cultures. J. Exp. Bot. 42(240): 911-915.

Dobránszki J and Silva JAT (2010) Micropropagation of apple: A review. Scientia Horticulturae, Biotechnology Advances. 28(4): 462-488.

Gamborg OL, Miller RA and Ojima K (1968) Nutrient requirements of suspension cultures of soybean root cells. Exp. Cell Res. 50: 151-158.

Goerge EF (1993) Somatic embryogenesis: Cell biological aspects. Acta Bot Neerl. 43: 1-14.

Komalavalli N and Rao MV (2000) In vitro micropropagation of Gymnema sylvestre - A multipurpose medicinal plant. Plant Cell Tiss. Org. Cult. 61: 97-105.

Linsmaier EM and Skoog F (1965) Organic growth factor requirements of tobacco tissue cultures. Physiol. Plant. 18: 100-127.

Lipavska $\mathbf{H}$ and Konradova $\mathbf{H}$ (2004) Somatic embryogenesis in conifers: The role of carbohydrate metabolism. In Vitro Cell Dev. Biol. Plant. 40: 23-30.

Nitsch J and Nitsch C (1969) Haploid plants from pollen grains. Sci. 163: 85-87.

Pandey V and Agrawal V (2009) Efficient micropropagation protocol of Spilanthes acmella L. possessing strong antimalarial activity. In Vitro Cell Dev. Biol. Plant. 45: 491-499.

Ramage CM and Williams RR (2002) Mineral nutrition and plant morphogenesis. In vitro Cell Dev. Biol. Plant. 38: 116-124.

Saritha KV, Prakash E, Ramamurthy M and Naidu CV (2002) Micropropagation of Spilanthes acmella Murr. Biol. Plantarum. 45(4): 581-584.

Tefera W and Wannakrairoj S (2004) Micropropagation of Krawan (Amomum krervanh Pierre ex Gagnep). Science Asia. 30: 9-15.

Tiwari KL, Jadhav SK and Joshi V (2011) An updated review on medicinal herb genus Spilanthes. J. Chin. Integr. Med. 9(11): 1170-1178.

Welander M, Welander NT and Brackman AS (1989) Regulation of in vitro shoot multiplication in Syringa, Alnus and Malus by different carbon sources. J. Hortic. Sci. 64(3): 361-366.

White PR (1963) The cultivation of animal and plant cells. Ronald press, New York. 